\title{
Renovation of apartment buildings with prefabricated modular panels
}

\author{
Kalle Kuusk ${ }^{1, *}$, Peep Pihelo ${ }^{1}$, and Targo Kalamees ${ }^{1}$ \\ ${ }^{1}$ Nearly Zero Energy Buildings Research Group, Tallinn University of Technology, Estonia
}

\begin{abstract}
New recast of the EPBD requires that that Member States shall establish a long-term strategy facilitating the cost-effective transformation of existing buildings into nearly-zero energy buildings. Lack of fund and lack of awareness is often considered to be the main barrier for the renovation. Experiences with renovation grant scheme in Estonia showed that large scale renovation scheme is a challenge to the construction industry and increased demand creates new problems like labour shortage and increased construction costs. Current renovation rate of apartment buildings in Estonia is approximately 200 buildings $(\sim 1 \%)$ per year. Demand is higher but current renovation technologies makes it difficult to significantly increase the renovation rate. Achieving the deep renovation goals with current technologies would require expansion of the whole construction sector (designers, contactors, material industry), which is difficult to achieve. Therefore, innovation and new technologies are needed. The prefabrication would be one solution to allow automation of the renovation process and renovate the existing housing stock within a reasonable time period.
\end{abstract}

\section{Introduction}

New recast of the energy performance of buildings Directive [1] requires that that Member States shall establish a long-term strategy facilitating the costeffective transformation of existing buildings into nearly-zero energy buildings. An average annual renovation rate of $3 \%$ would be needed to accomplish the energy efficiency ambitions. Today, the renovation rate is around $1 \%$. Less than $3 \%$ of the building stock in the European Union has an Energy Performance Certificate label A (nearly-zero energy building) [2]. To achieve the goal to transform the existing buildings into nearly- zero energy buildings, $97 \%$ of the building stock must be upgraded. European Construction Sector observatory report [3] concluded that the construction sector has an ageing workforce and is experiencing a skill shortage. Off-site industrialisation and use of prefabricated building elements for the renovation represents a solution to automate the renovation process and renovate the existing housing stock within a reasonable time period. The industrialised process for new constructions is widely used all over Europe. The challenge will be to adapt the industrialisation to the renovation market as industrialised approach for renovations is not yet well-established [4].

The paper presents the experiences from the first nearlyzero energy renovation in Estonia. The pilot renovation was conducted with the prefabricated modular panels.

\section{Housing stock in Estonia}

\subsection{Apartment buildings}

Main share of the housing stock in Estonia was built during the industrial construction period 1970-1990.

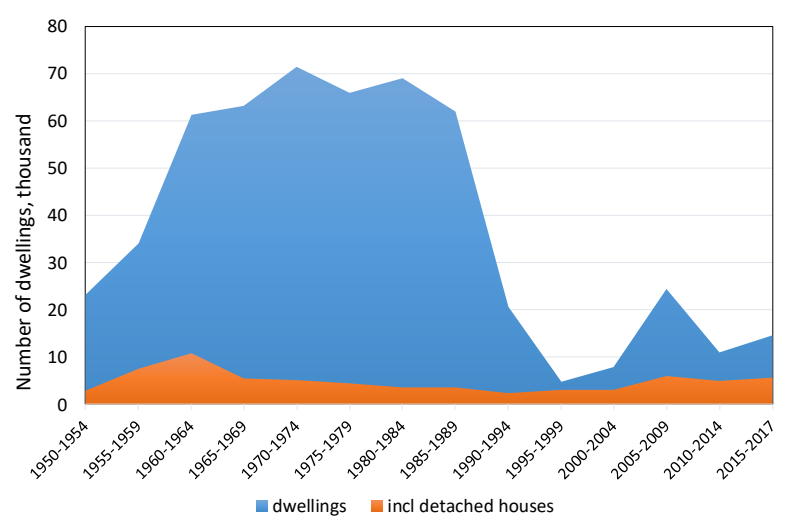

Fig. 1. Housing stock by construction time.

Apartment buildings from the industrial construction era have similar problems: high energy consumption and poor indoor climate conditions. Thermal transmittance values for the external walls of the apartment buildings were $\mathrm{U} \approx 0.8 \ldots 1.6 \mathrm{~W} /\left(\mathrm{m}^{2} \cdot \mathrm{K}\right)$. For comparison, the current recommendation for new residential buildings for thermal transmittance for external walls is $\mathrm{U} \approx 0.12$ $0.15 \mathrm{~W} /\left(\mathrm{m}^{2} \cdot \mathrm{K}\right)$.

\footnotetext{
* Corresponding author: kalle.kuusk@,taltech.ee
} 
Based on the main construction materials that have been used, there are four main apartment building types: wood, autoclaved aerated concrete large blocks, brick, and prefabricated reinforced concrete large panels. Older wooden apartment buildings are often located on the milieu value areas and have certain restrictions for the renovation works. Other types of apartment buildings are suitable for the modular prefabricated renovation solution.
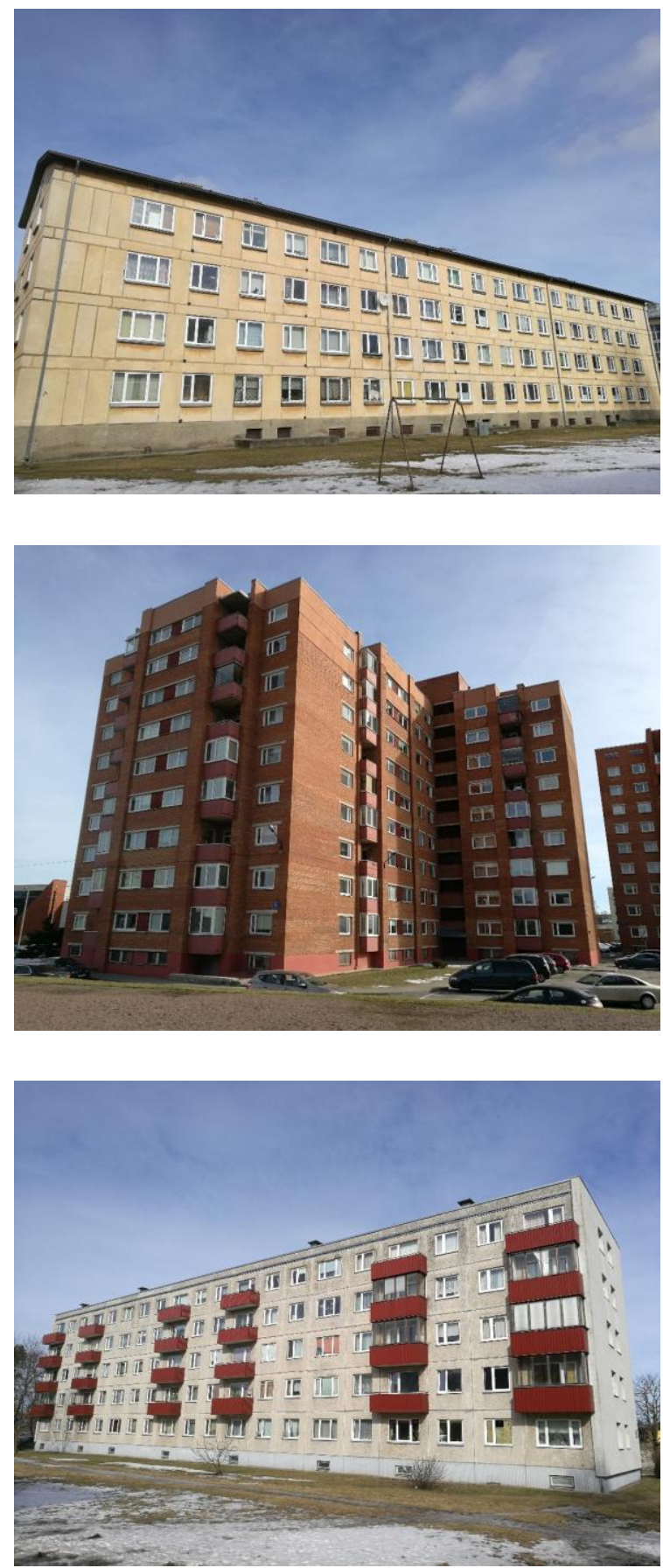

Fig. 2. Main apartment building types by construction materials. From top: autoclaved aerated concrete large blocks, brick, prefabricated reinforced concrete large panels.
Most of existing apartments buildings have been in use 30 to 40 years without major renovation and are in need for deep renovation. The average heating energy consumption level for existing apartment buildings in Estonia is approximately $140-150 \mathrm{kWh} /\left(\mathrm{m}^{2} \cdot \mathrm{a}\right) \quad$ [5]. Existing apartment buildings are mainly in EPC classes E or F.

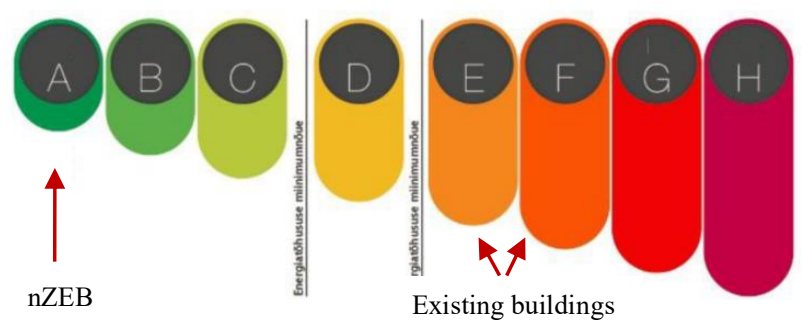

Fig. 3. Energy Performance Certificate labels scale in Estonia.

\subsection{Ownership}

In Estonia, a total of $82 \%$ of dwellings are privately owned [6] and owner occupied. Apartment buildings are generally managed by apartment associations. Apartment associations are non-profit legal bodies where all apartment owners are members. Main decisions are made in general assembly with voting (simple majority) which means that more than $50 \%$ of apartment owners in each building must agree on the volume of any renovation work and on the budget for any such work. This makes large-scale and systematic process of renovating apartment buildings a complicated one. Renovation works are expensive and energy savings from renovation may not be enough to keep the total cost (renovation loan, maintenance and energy) after the deep renovation at an acceptable level for apartment owners.

\subsection{Renovation grant for apartment buildings}

During the period 2015-2017, renovation grant scheme for apartment buildings was available in Estonia. There were three renovation grant share levels for construction works $(15 \%, 25 \%$, and $40 \%)$. These were divided based on the designed energy efficiency level that will be achieved after renovation work has been completed. A $15 \%$ grant could applied when EPC Class E (minor renovation works) was achieved after the completion of renovation works, while a $25 \%$ grant could applied when EPC Class D (energy efficiency requirement for major renovation) was achieved after the completion of renovation works, and a $40 \%$ grant could applied when EPC Class C (energy efficiency requirement for new apartment buildings) was achieved after the completion of renovation works. In total, over 400 apartment buildings were renovated within grant scheme and over $90 \%$ of renovations were $40 \%$ grant renovations which means deep integrated renovation.

In addition to the EPC class, requirements were also in place for thermal transmittance in the building envelope, the heating system, and the ventilation system. For $40 \%$ 
grant renovation, requirement for thermal transmittance of external walls was $\mathrm{U}-0.22 \mathrm{~W} /\left(\mathrm{m}^{2} \mathrm{~K}\right)$, for roof $\mathrm{U}-0.12$ $\mathrm{W} /\left(\mathrm{m}^{2} \mathrm{~K}\right)$, and for windows $\mathrm{U}-1.1 \mathrm{~W} /\left(\mathrm{m}^{2} \mathrm{~K}\right)$. The heating system had two requirements: the system must be balanced, and radiators must be equipped with thermostats in order to allow room-based indoor temperature control. For ventilation, a mechanical ventilation with heat recovery must be installed.

Start of the renovation grant scheme was slow with less than 10 application per month. Decision making process in apartment associations is relatively long and contractors also needed time to gain experiences with the new technical conditions. It took approximately two years to reach the level of 30 applications per month.

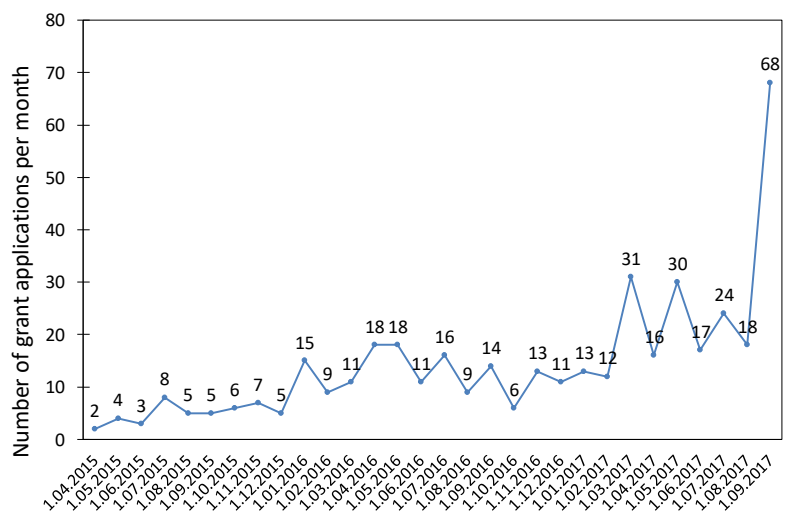

Fig. 4. Number of grant applications per month.

Tripled volumes created new problems with shortage of contactors, construction workers and construction materials. That resulted with the increase of renovation costs. Average renovation cost in 2015 was $247 € /$ net $\mathrm{m}^{2}$. In 2017, average renovation cost was $297 € /$ net $\mathrm{m}^{2}$ which makes a $20 \%$ construction cost increase in relatively short time period.

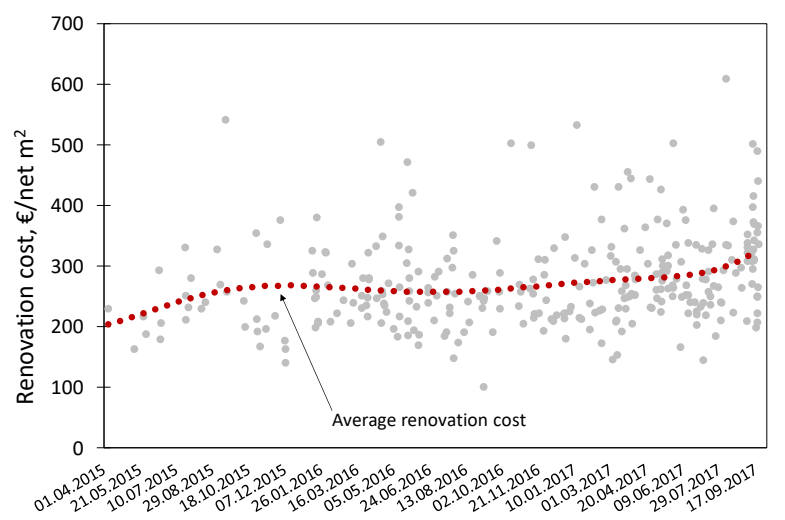

Fig. 5. Change of average renovation cost.

Experiences with renovation grant scheme in Estonia showed that large scale renovation scheme is a challenge not only for the apartment associations but also to the construction industry. Increased demand creates new problems like shortage of contractors and increased construction costs.

\section{Renovation \\ with \\ prefabricated modular panels}

\subsection{Case study building}

The pilot building is a typical 5-storey house, built in 1986 and made of prefabricated concrete large panel elements and analogous to mass production apartment buildings (series 111-121) from 1960-1990. The building has a simple, rectangular floor plan with 2 similar wings, 2 stairways, and with similarly designed flats. The net area of the building is $3824 \mathrm{~m}^{2}$.
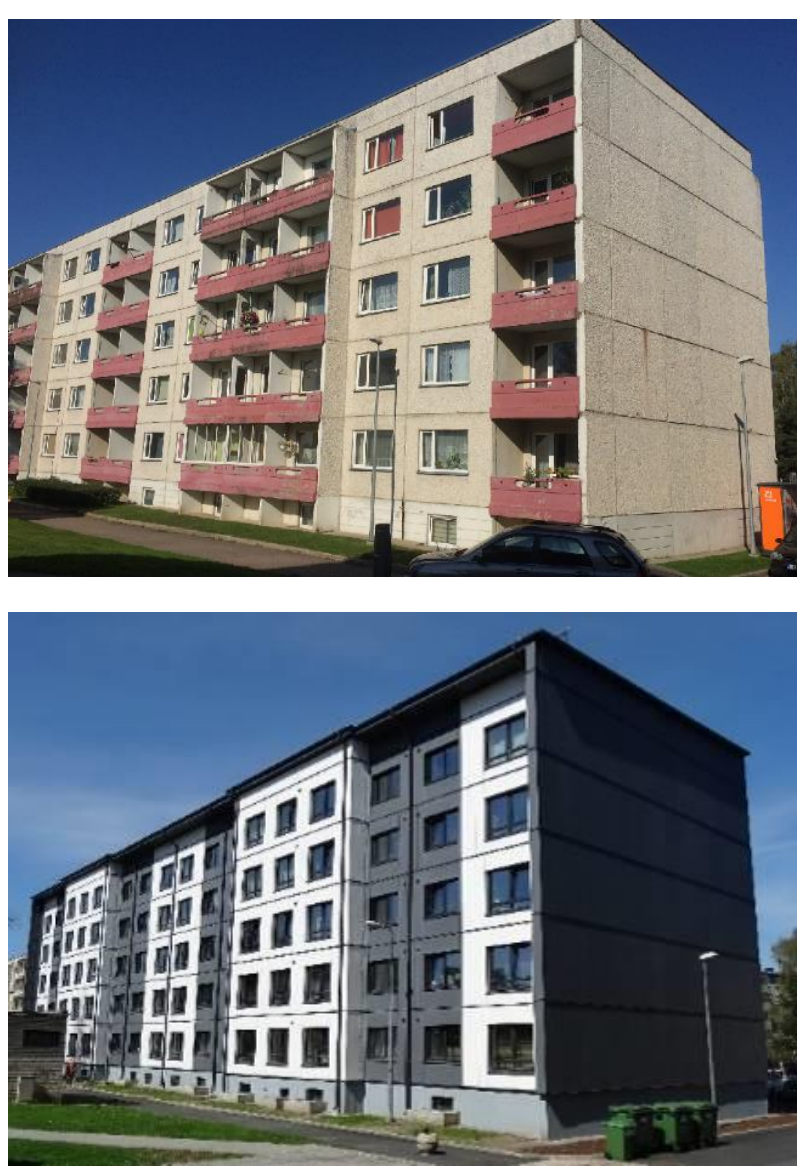

Fig. 6. View of the pilot building before (above) and after (below) the renovation.

Existing 250mm concrete panel exterior wall consists of 2 concrete sections and insulation layers: $60 \mathrm{~mm}$ external reinforced concrete slab $+70 \mathrm{~mm}$ wood-chip insulation layer $+50 \mathrm{~mm}$ phenolic foam insulation layer $+70 \mathrm{~mm}$ internal reinforced concrete slab. The existing flat roof with parapet is covered with bitumen felt and insulated with wood-chip boards.

Building had natural ventilation system with central ventilation shafts and one-pipe radiator heating system without thermostats. Room temperature for the whole building was regulated by a heat substation depending on the outdoor temperature. 


\subsection{Renovation solution}

\subsubsection{Facade solutions}

The building envelope above ground is insulated with prefabricated modular panels. Basement walls are insulated with an external thermal insulation composite system. Prefabricated modular panels consist of a timber frame structure filled with mineral wool. To get accurate information about the existing surfaces and inhomogeneity of windows location, 3D laser scanning of the envelope was conducted before the design.

The total thickness of designed modular wall elements is $340-380 \mathrm{~mm}$, depending on the surface flatness of the existing wall: $30 \mathrm{~mm}$ wind barrier, $70+195 \mathrm{~mm}$ insulation between timber frames and $10-50 \mathrm{~mm}$ light elastic mineral wool to fill the unevenness and roughness of the existing surfaces, $\mathrm{U}_{\text {wall }}=0.11 \mathrm{~W} /\left(\mathrm{m}^{2} \cdot \mathrm{K}\right)$.

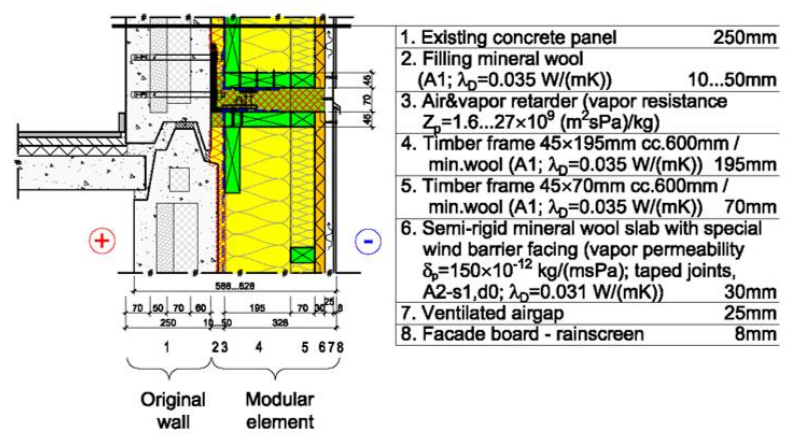

Fig. 7. Section of the external wall with prefabricated element.

In the wall panel with dimensions $\sim 2.7 \times 9 \mathrm{~m}$ are up to three preinstalled windows. The existing balconies were demolished and rebuilt as an additional space for living rooms, therefore the module panels are used in front of former balconies spaces. After the installation the joints between the panels were filled with PU-foam for the airtightness of the envelope and covered with wind barrier and steel bands against rainwater penetration into the structures.

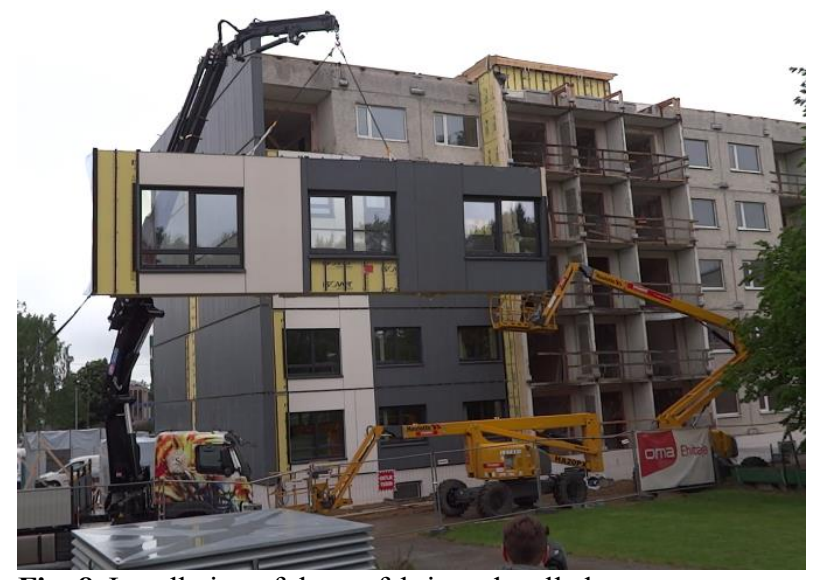

Fig. 8. Installation of the prefabricated wall element.
Regarding the structural support, there is no additional foundation for the external wall module panels. Prefabricated modules are hanged with the help of adjustable fixings (hangers).
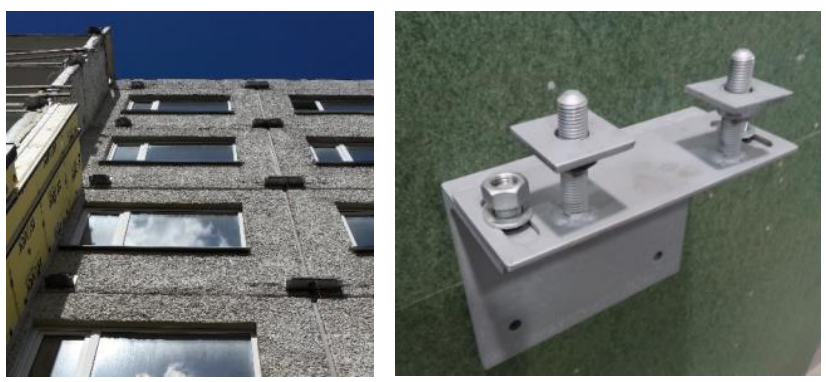

Fig. 9. Adjustable fixings (hangers) of wall module panels.

\subsubsection{Roof solutions}

Designed roof elements are installed on the specially built timber frame because the original roof has an inward slope and parapet. Therefore, under the formed slope roof, in $0.6-1.2 \mathrm{~m}$ high attic between old and new roof which was used for ventilation ducts. The total thickness of the thermal insulation in the roof modules is $340 \mathrm{~mm}, \mathrm{U}_{\text {roof }}=0.10 \mathrm{~W} /\left(\mathrm{m}^{2} \cdot \mathrm{K}\right)$.

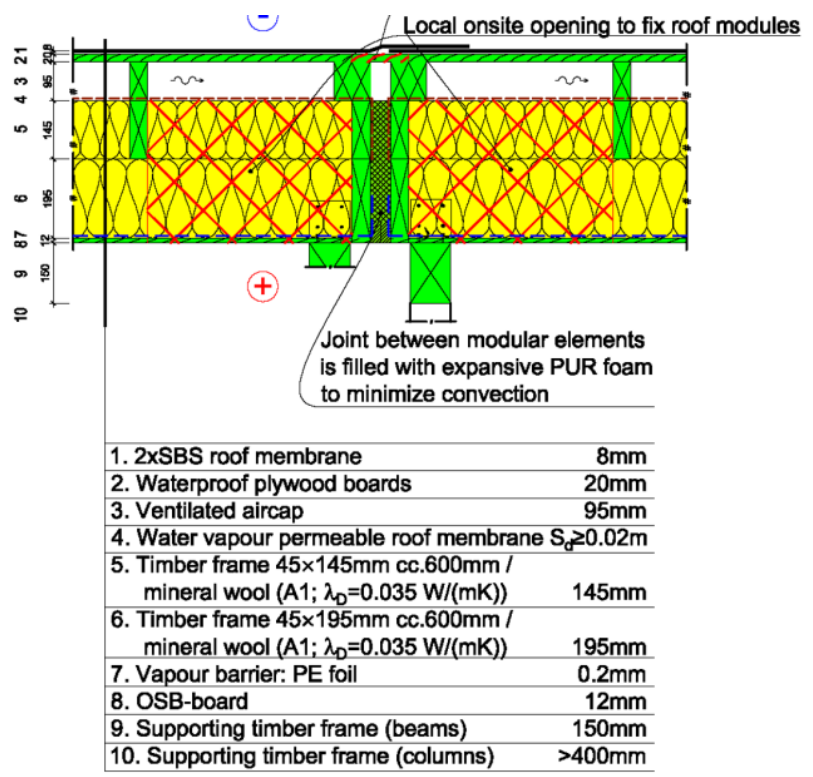

Fig. 10. Section of the roof element. 


\subsubsection{Ventilation and heating system}

New ventilation system with heat recovery was installed. Ventilation ducts are embedded into the wall module elements. The ventilation unit with heat exchanger is on the roof. To minimize the connections of pipes on site, the panels with ventilation ducts were installed in vertical direction.

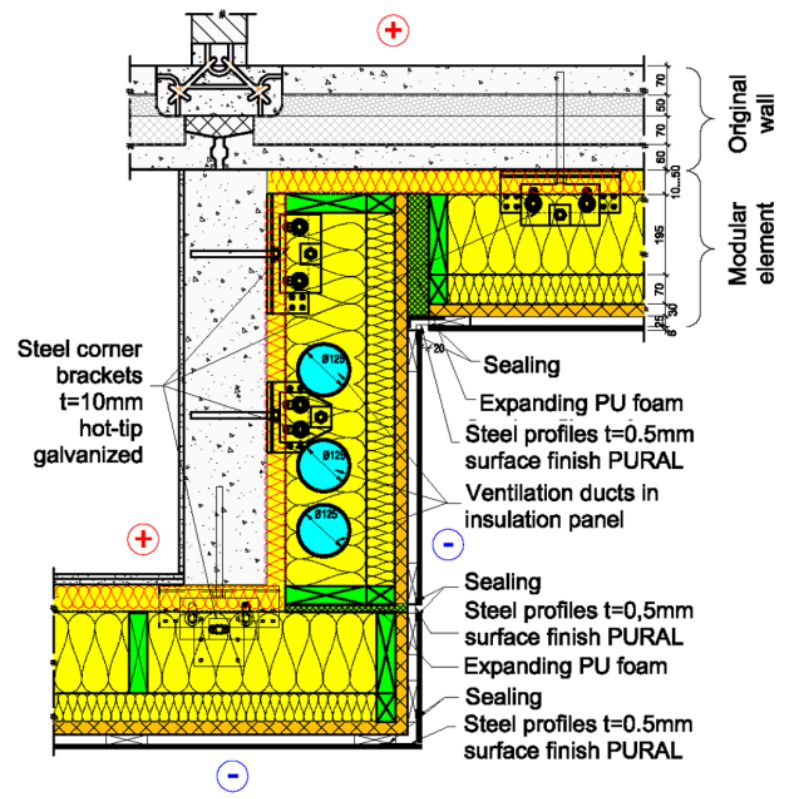

Fig. 11. Ventilation ducts inside the wall module element.

The old one-pipe heating system was replaced with a new two-pipe system including new radiators with thermostats. District heating remained as heat source.

\subsubsection{Renewable energy}

PV-panels (55 panels with total power of $14 \mathrm{~kW}$ ) and solar collectors (50 panels with total effective area of $100 \mathrm{~m}^{2}$ ) were installed on the roof. In addition to the PVpanels, solar collectors are used because the pilot building is a university dormitory for students with small children. This means that water consumption is higher than in average apartment buildings and use of solar collectors for heating the hot water is reasonable.

In addition, a waste-water heat recovery system was installed to the one wing of building. Grey water (showers and sinks) is collected separately and guided through the heat recovery system. Waste-water heat is used to pre-heat the incoming cold water before the heating sub-station.

\section{Discussion}

The pilot building was the first renovated apartment building in Estonia with the prefabricated elements. Results are similar to the others project in Europe [7][8][9]: prefabrication is an efficient solution for the energy renovation, it allows to guarantee a better quality and it makes possible to renovate quickly without using scaffoldings. For country level perspective, the installation speed would allow to increase the renovation volumes. Estimations are that insulating external walls with prefabricated panels would take approximately 2-3 weeks compared to the 2-3 months with current technologies. Current renovation rate of apartment buildings in Estonia is approximately $1 \% \quad(\sim 200$ buildings) per year. Demand is higher but current renovation technologies makes it difficult to significantly increase the renovation rate.

Although prefabrication have shown its benefits in many studies, it is not become widely used renovation solution. Study about the prefabricated housing [10] concluded that prefabrication uptake in new building sectors is driven by a peak in demand and consumer preference for new housing over renovations. One of the barriers for the wider use of prefabrication for housing stock renovation is also the cost of prefabricated elements. Cost of the pilot building prefabricated wooden insulation panels was $\sim 180 € /$ wall $\mathrm{m}^{2}$ including installation and taxes. Current main solution for the external wall insulation in renovation projects are external thermal insulation composite system (ETICS) and ventilated façade. ETIC system is preferred insulation solution in the renovation market because of the lowest investment cost (finished construction with $150 \mathrm{~mm}$ insulation $\sim 70 € / \mathrm{wall}^{2}$ ). Previous study about the deep renovation of apartment buildings in Estonia [11] found that even with the $40 \%$ grant, the total cost (renovation loan, maintenance and energy) for the occupants increase $10-20 \%$ after the renovation. Wider use of prefabrication would help to increase the renovation volumes but at least at the moment, is not affordable for the wider renovation market.

The pilot building was renovated to meet the nZEB (EPC class A) energy efficiency level. For renovation, EPC class A is not yet a cost-optimal solution. Current cost-optimal level for renovation is EPC class C [12]. For renovation market aiming the EPC class C renovation, the thermal transmittance of the prefabricated modular panel can be higher than it was for the pilot renovation aiming nZEB level. One suitable solution would be for example $30 \mathrm{~mm}$ wind barrier, $145 \mathrm{~mm}$ insulation between timber frames and $10-50 \mathrm{~mm}$ light elastic mineral wool to fill the unevenness and roughness of the existing surfaces, $U_{\text {wall }}=0.15 \mathrm{~W} /\left(\mathrm{m}^{2} \cdot \mathrm{K}\right)$ [13]. Simpler and lighter prefabricated insulation panel would be more affordable and benefits of the prefabrication such as quality, durability and shorter renovation time would have an effect when home owners choose the renovation solution. 


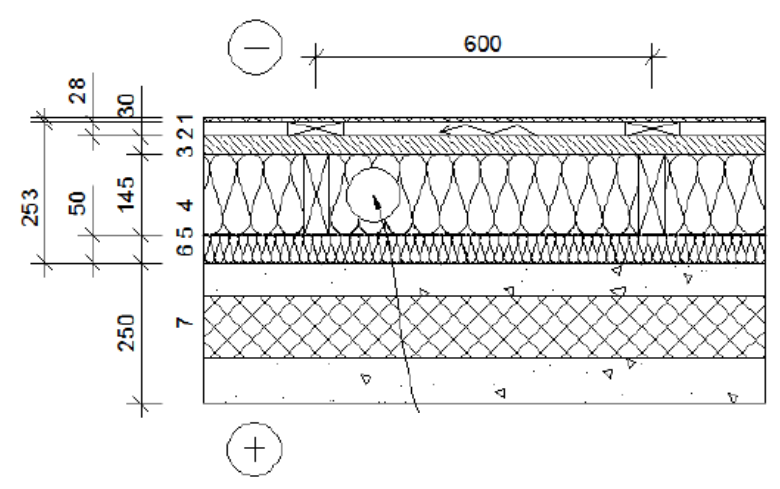

Fig. 7. Section of the simplified prefabricated element.

But even with the simpler wall insulation panel for the renovation market, the cost would be $\sim 150 € /$ wall $\mathrm{m}^{2}$ including installation and taxes [13]. Current estimations show that possibilities to significantly lower the production cost with only simplifying the prefabricated elements are limited. Cost problem may be relieved by future cost reductions due to economies of scale and larger production volumes. If they are achieved, the prefabricated renovation solution could be one of the widely used solutions in future renovation projects. However, more research and development work or external stimulation of market demand is still needed for that.

\section{Conclusions}

Renovation grant scheme in Estonia showed that increased demand creates new problems like shortage of contractors and increased construction costs. Achieving the deep renovation goals with current technologies would require expansion of the whole construction sector (designers, contactors, material industry), which is difficult to achieve. The prefabrication would be one solution to automate the renovation process and renovate the existing housing stock within a reasonable time period. With the affordable product for the renovation, there would be considerable market demand for the renovation with prefabricated elements. For wider level perspective, the prefabrication would allow to increase the renovation volumes and help to achieve the coal of transformation of existing buildings into nearly-zero energy buildings.

\section{Acknowledgements}

This research was supported by the Estonian Centre of Excellence in Zero Energy and Resource Efficient Smart Buildings and Districts, ZEBE, grant TK146 funded by the European Regional Development Fund, and by the Personal research funding grant PRG483, Moisture safety of interior insulation, constructional moisture and thermally efficient building envelope and by EU funded Horizon 2020 project "Development and advanced prefabrication of innovative, multifunctional building envelope elements for modular retrofitting and smart connections (MORE-CONNECT)".

\section{References}

1. The energy performance of buildings Directive (EU) 2018/844 of 30 May 2018.

2. Buildings Performance Institute Europe. 97\% of buildings in the EU need to be upgraded. http://bpie.eu/publication/97-of-buildings-in-the-euneed-to-be-upgraded/

3. European Construction Sector Observatory https://ec.europa.eu/docsroom/documents/24261

4. Buildings Performance Institute Europe. Prefabricated systems for deep energy retrofits of residential buildings. content/uploads/2016/02/Deep-dive-1-Prefabsystems.pdf

5. Kuusk, K (2015). Integrated cost-optimal renovation of apartment buildings toward nearly zero-energy buildings. Doctoral thesis, Tallinn University of Technology.

6. Pittini, A., Ghekiere, L., Dijol, J., Kiss, I. 2015. The state of housing in the EU 2015.

7. Malacarne, G., Pasetti Monizza, G., Ratajczak, J., Krause, D., Benedetti, C., Matt, T.D. 2016. Prefabricated timber façade for the energy refurbishment of the Italian building stock: the Ri.Fa.Re. project. Energy Procedia 96788 - 799.

8. Sandberg, K., Orskaug, T., Andersson, A. 2016. Prefabricated wood elements for sustainable renovation of residential building façades. Energy Procedia 96756 $-767$.

9. Martinez, R.G., Ayucar J.B., Goikolea B.A. 2017. Full scale experimental performance assessment of a prefabricated timber panel for the energy retrofitting of multi-rise buildings. Energy Procedia 122 3-8.

10. Steinhart D.A., Manley, K. 2016. Adoption of prefabricated housing - the role of country context. Sustainable Cities and Society 22 126-135.

11. Kuusk, K.; Kalamees, T. (2016). Estonian Grant Scheme for Renovating Apartment Buildings. Energy Procedia: SBE16 Tallinn and Helsinki Conference Build Green and Renovate Deep, 5-7 October 2016, Tallinn and Helsinki.

12. Arumägi, E., Simson R., Kuusk K., Kalamees T., Kurnitski J. 2017. Analysis of cost-optimal minimum energy efficiency requirements for buildings.

13. Ojarand, M.L. 2018. The analysis and development of prefabricated reconstruction elements. Master thesis (in Estonian). 